\title{
Formula feeding for late-preterm infants
}

\author{
Luigi Corvaglia*, Arianna Aceti \\ From XX National Congress of the Italian Society of Neonatology \\ Rome, Italy. 9-11 October 2014
}

Preterm birth interrupts physiological foetal development, leading to various degrees of immaturity according to the gestational age at which the infant is born [1].

Since 2005, the imprecise definition of "near-term" infants has been replaced with "late-preterm", which includes infants born between $34^{0 / 7}$ and $36^{6 / 7}$ weeks of gestation [2]. Late-preterm infants are at higher risk than term infants of developing medical complications that result in higher rates of mortality and morbidity [3], including thermal instability, respiratory problems, hypoglycaemia, jaundice, and feeding problems.

Breastfeeding is the first nutritional choice for all infants, especially for those born preterm. The establishment of successful breastfeeding in late-preterm infants is usually problematic, as late-preterm infants can be sleepier, have less muscular strength and more difficulty with latch, suck and swallow than term infants [4]. For this reason, health-care providers should implement specific strategies aimed at anticipate, identify promptly, and manage breastfeeding problems that the late-preterm infant and mother can experience.

However, when exclusive breastfeeding does not guarantee adequate nutrition, supplements might be advisable. Nutritional requirements of late-preterm infants are currently derived from speculations on foetal growth and requirements of preterm and term infants, while specific data on nutritional needs of this population are scarce. There is currently no consensus on whether late-preterm infants would benefit most of a high-protein diet, such as that proposed for "micropreterm" infants [5], or of a lowprotein diet, such as that recommended for full-term infants. Some studies suggest that the provision of extra protein and energy could reduce weight loss and increase growth velocity [6], thus decreasing the risk for dehydration and hospital readmission. However, it is important to note that growth rate during late gestation decreases

Neonatology and Neonatal Intensive Care Unit S.Orsola-Malpighi Hospital, Department of Medical and Surgical Sciences (DIMEC), University of Bologna, Italy

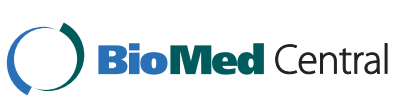

(c) 2014 Corvaglia and Aceti; licensee BioMed Central Ltd. This is an Open Access article distributed under the terms of the Creative Commons Attribution License (http://creativecommons.org/licenses/by/4.0), which permits unrestricted use, distribution, and reproduction in any medium, provided the original work is properly cited. The Creative Commons Public Domain Dedication waiver (http://creativecommons.org/publicdomain/zero/1.0/) applies to the data made available in this article, unless otherwise stated. dramatically, and it is likely that protein and energy requirements for infants born during this period wouldn't be as high as those of very preterm infants [7].

Current guidelines recommend the supplementation with essential nutrients also for late-preterm infants. Actually, it has been shown that supplementation with LC-PUFAs improves visual acuity and cognitive development in infants 30-37 weeks gestation [8].

The best nutritional approach to late-preterm infants still needs to be determined. Human milk's benefits are undoubted; however, caregivers have to adequately support the establishment of successful breastfeeding and also identify those cases where some supplementation is needed. Further studies will have to clarify whether all late-preterm infants, or only a subgroup such as smallfor-gestational-age infants, could benefit from formulas with high energy and protein content.

Published: 9 October 2014

\section{References}

1. Raju TNK: Developmental physiology of late and moderate prematurity. Semin Fetal Neonatal Med 2012, 17:126-31.

2. Raju TNK, Higgins RD, Stark AR, Leveno KJ: Optimizing care and outcome for late-preterm (near-term) infants: a summary of the workshop sponsored by the National Institute of Child Health and Human Development. Pediatrics 2006, 118:1207-14.

3. Engle Wa, Tomashek KM, Wallman C: "Late-preterm" infants: a population at risk. Pediatrics 2007, 120:1390-401.

4. The Academy of Breastfeeding Medicine: ABM clinical protocol \#10: breastfeeding the late preterm infant $(34(0 / 7)$ to $36(6 / 7)$ weeks gestation) (first revision June 2011). Breastfeed Med 2011, 6:151-6.

5. Tudehope D, Fewtrell M, Kashyap S, Udaeta E: Nutritional needs of the micropreterm infant. J Pediatr 2013, 162(3 Suppl):S72-80.

6. Blackwell MT, Eichenwald EC, McAlmon K, Petit K, Linton PT, McCormick MC, Richardson DK: Interneonatal intensive care unit variation in growth rates and feeding practices in healthy moderately premature infants. J Perinatol 2005, 25:478-85.

7. Lapillonne A, O'Connor DL, Wang D, Rigo J: Nutritional recommendations for the late-preterm infant and the preterm infant after hospital discharge. J Pediatr 2013, 162(3 Suppl):S90-100.

8. Fang $P$, Kuo H, Huang C, Ko T, Chen C, Chung M: The effect of supplementation of docosahexaenoic acid and arachidonic acid on visual acuity and neurodevelopment in larger preterm infants. Chang Gung Med J 2005, 28:708-715. 
doi:10.1186/1824-7288-40-S2-A37

Cite this article as: Corvaglia and Aceti: Formula feeding for late-

preterm infants. Italian Journal of Pediatrics 2014 40(Suppl 2):A37.

Submit your next manuscript to BioMed Central and take full advantage of:

- Convenient online submission

- Thorough peer review

- No space constraints or color figure charges

- Immediate publication on acceptance

- Inclusion in PubMed, CAS, Scopus and Google Scholar

- Research which is freely available for redistribution

Submit your manuscript at 